\title{
Occupational health and safety cases in the New Zealand District Court
}

\author{
CHRISTOPHER PEACE* and PIPPI PRIESTLEY-KING ${ }^{* *}$
}

\begin{abstract}
Occupational health and safety (OHS) practitioners need to understand prosecutions that have been before the District Court if they are to provide informed guidance about compliance with the New Zealand (NZ) Health and Safety at Work Act (HSWA) to "persons having control of a business or undertaking" (PCBUs). However, if they cannot access academic databases, they may need to rely on individual reports of a few cases but may not have the time or resources to develop their own database. Those who are studying for a tertiary level qualification may also lack the time to find and catalogue more than a few cases.
\end{abstract}

This short article reports on the first stage of the development and analysis of a dataset of prosecutions under NZ OHS legislation. We describe our data sources and a high-level analysis of the dataset and issues to be resolved before proceeding with further data analysis. This work also forms part of research into "grey literature" and its use in practice by OHS practitioners and professionals.

We conclude by showing the disparity between prosecutions and deaths due to occupational disease and trauma (leading to an area for further research) and loop back to one of the origins for this research: the meaning of a safe system of work.

Keywords: prosecution, enforceable undertaking, occupational health and safety, compliance, grey literature, legislation

\subsection{Background}

The International Network of Safety and Health Practitioner Organisations (INSHPO, 2017) framework sets out requirements for the capabilities of OHS practitioners and professionals. Qualifications must meet those requirements if they are to be recognised. For example, INSHPO requires that "professionals must ... lead and facilitate OHS knowledge and skill development ... to meet legal and risk management requirements" (p. 26). Professionals must also understand "legal principles and comparative legal systems and regulatory frameworks" (p. 27). Meeting those requirements at Victoria University of Wellington, Te Whare Wānanga o te Ūpoko o te Ika a Māui, led to a description of the development of OHS legislation in $\mathrm{NZ}$ and its effects on the profession

\footnotetext{
* Lecturer in Occupational Health and Safety, Victoria University of Wellington http://orcid.org/0000-0003-0688-6263

Email: christopher.peace@vuw.ac.nz

${ }^{* *}$ Research Assistant
}

\section{Acknowledgements, funding and authorship}

The comments of an anonymous reviewer are acknowledged.

This research did not receive any funding from public, commercial, or not-for-profit entities.

PPK researched and entered the data; $\mathrm{CP}$ drafted this preliminary analysis and article. 
(Peace et al., 2019). However, the lack of a body of knowledge of prosecutions under NZ OHS legislation reduced the ability to apply that knowledge to practice.

The New Zealand Health and Safety at Work Act (HSWA) 2015 is derived from the Australian Model Work Health and Safety Bill (2011) which, in turn, has its origins in the UK Health and Safety at Work Act (1974). The UK Act followed the recommendations of the report by Lord Robens et al. (1972). Thus, this, and planned research, may be of interest internationally.

An investigation of the meaning of a safe system of work under the NZ HSWA (Peace et al., 2021) considered only a few results of cases heard in the NZ District Court as they had not been catalogued to enable easy searching. That article noted that work was proceeding on cataloguing more cases.

This article reports on a stage in a project that responds to these professional development and teaching needs for a searchable dataset of OHS court cases in NZ and a preliminary analysis of the data. We place such cases as items of "grey literature" (Auger, 2017) forming part of a wider research agenda on such sources (Adams et al., 2017; Mahood et al., 2014) in OHS.

\subsection{Methodology}

Full, machine-readable decisions on 117 cases were found on the District Court website (https://www.districtcourts.govt.nz/). A further 84 records were found in newspaper or magazine articles reporting cases, the WorkSafe NZ website (https://www.worksafe.govt.nz/) and Maritime NZ website (https://www.maritimenz.govt.nz/). The WorkSafe records included scanned copies of judges' sentencing notes that were not machine-readable and the Maritime NZ reports were summaries of cases. This group of 201 records has been entered into Endnote or used to update existing Endnote records. Further searching has located more cases and work continues to record them or update existing entries.

Bibliographic data for the Endnote entries includes (when available):

- case name as recorded in the judge's decisions

- year when a case was decided

- name of the judge hearing the case

- the location of the District Court where the case was heard

- docket number of the hearing.

In addition, the records include (when available):

- the legislation under which charges were laid

- key words selected by us

- an extract from the judge's sentencing notes

- notes for the purposes of the Endnote database user

- text from newspaper or magazine articles about a case.

During this stage of the project, records of enforceable undertakings (subpart 4 of the NZ HSWA) were found and work entering them in Endnote has started.

\subsection{Preliminary analysis}


The following is a preliminary analysis of the 201 cases and must be seen as incomplete as we lacked full data on all cases. For example, in some instances we relied on newspaper articles that did not give full information about cases.

\subsection{Judges and District Court locations}

The 201 cases were heard by 23 different District Court judges. The number of cases heard by each judge ranged from one (four judges) up to seven (two judges). There are 59 District Court locations in New Zealand. However, OHS-related cases were heard in only 44 of them in the period 2015-2021. The District Courts where six or more cases have been heard are shown in Table 1.

Table 1. District Courts where cases have been heard ranked in descending order

\begin{tabular}{|l|l|}
\hline Location of District Court & $\begin{array}{l}\text { Number of cases heard } \\
\mathbf{2 0 1 5 - 2 0 2 1}\end{array}$ \\
\hline Auckland & 27 \\
\hline Christchurch & 23 \\
\hline Tauranga & 17 \\
\hline Wellington & 14 \\
\hline Manukau & 10 \\
\hline Hamilton & 8 \\
\hline Nelson & 8 \\
\hline Queenstown & 8 \\
\hline Hastings & 7 \\
\hline Whangarei & 7 \\
\hline Dunedin & 6 \\
\hline North Shore & 6 \\
\hline
\end{tabular}

\subsection{Keywords}

The keywords included terms apparently relevant to the available information. However, on review we found inconsistencies in our keywords that need to be remedied as part of the continuing research. Also, we did not use Statistics NZ (2006) codes to classify the business activity leading to the prosecution or other enforcement activity. This also needs to be remedied as part of planned research that will use this data.

Commonly used keywords and the number of uses are listed in Table 2 (NB: several keywords might be used in some cases, making the total used more than 201). Section 16 HSWA defines "plant" to include:

(a) any machinery, vehicle, vessel, aircraft, equipment (including personal protective equipment), appliance, container, implement, or tool; and

(b) any component of any of those things; and

(c) anything fitted or connected to any of those things.

The keyword "plant" was used where relevant but sometimes the keywords machinery, vehicle, vessel, aircraft or equipment were also used.

Table 2. Key words sorted by number of occurrences

\begin{tabular}{|c|l|}
\hline Key word & $\begin{array}{l}\text { Number of times } \\
\text { used }\end{array}$ \\
\hline Machine & 80 \\
\hline
\end{tabular}




\begin{tabular}{|l|l|}
\hline Plant & 76 \\
\hline System & 54 \\
\hline Fall & 42 \\
\hline Fatal & 42 \\
\hline Public & 32 \\
\hline Construction & 31 \\
\hline Height & 21 \\
\hline Farm & 20 \\
\hline Fatality AND plant & 16 \\
\hline Agriculture & 11 \\
\hline Chemical & 11 \\
\hline Hazardous substance & 10 \\
\hline Asbestos & 5 \\
\hline Electricity & 5 \\
\hline Health & 5 \\
\hline Quad bike & 4 \\
\hline Marine (but not as in Maritime NZ) & 3 \\
\hline Waste & 3 \\
\hline Disease & 3 \\
\hline
\end{tabular}

Search for the keyword "fatality" found 42 cases involving one or more traumatic deaths, 16 of which had the two keywords "fatality" and "plant". Only five of the cases involved actual or potential harm to the health of workers due to asbestos, dust, or microbiological agents. This provides a stark contrast between the number of deaths per year due to trauma - typically 50-80, and occupational disease typically 750-900 (Worksafe NZ, 2019) - providing an opportunity to explore the absence of "health" from the duty in section 36 HSWA for a safe system of work.

\subsection{Legislation}

The legislation under which prosecutions were taken was recorded if it was explicitly stated in a source or clearly implied and is summarised in

Table 3. The Health and Safety in Employment Act 1992 was repealed by the HSWA 2015 with effect from 1 April 2016.

From this dataset, prosecutions under the Health and Safety in Employment Act 1992 concluded in 2017, with one consequential appeal to the High Court in 2018. Prosecutions under the HSWA began to be decided in the District Court in 2017. It is estimated that five convictions have been appealed to the High Court; these will also be researched and added to the dataset.

One set of 13 cases before the District Court following the Whakaari/White Island tragedy relate to alleged breaches of the HSWA and Health and Safety at Work (Adventure Activities) Regulations. They are currently recorded as a single case. Other adventure activities cases under the Health and Safety in Employment Act 1992 and Maritime Transport Act 1994 also touch on adventure activities and will be explored more fully in a future article.

Table 3. Legislation under which prosecutions were taken (in descending order of numbers)

\begin{tabular}{|c|l|}
\hline Act or Regulations & $\begin{array}{l}\text { Number } \\
\text { prosecutions }\end{array}$ \\
\hline Health and Safety at Work Act 2015 & 108 \\
\hline
\end{tabular}




\begin{tabular}{|l|l|}
\hline Health and Safety in Employment Act 1992 & 75 \\
\hline Maritime Transport Act 1994 & 6 \\
\hline Electricity Act 1992 & 3 \\
\hline Gas Act 1992 & 2 \\
\hline Amusement Devices Regulations 1978 & 1 \\
\hline $\begin{array}{l}\text { Health and Safety at Work (Asbestos) Regulations } \\
2016\end{array}$ & 1 \\
\hline Health Act (related to Covid-19) & 1 \\
\hline Plumbers, Gasfitters and Drainlayers Act 2006 & 1 \\
\hline $\begin{array}{l}\text { Health and Safety at Work (Adventure Activities) } \\
\text { Regulations 2016 }\end{array}$ & 1 \\
\hline
\end{tabular}

The records showed five prosecutions for breaches of section 34 HSWA which requires holders of shared duties under the Act to "consult, co-operate with and co-ordinate activities". Six prosecutions were taken under section 45(b) HSWA (the duty of a worker).

Three prosecutions were taken for breaches of section 44 HSWA (the due diligence duty of "officers"). Earlier work on the implications of section 44 (Peace et al., 2017) can be reviewed and revised in the light of these cases and subsequent research from elsewhere.

\subsection{Discussion}

This work provides a preliminary view of an emerging body of $21^{\text {st }}$ century OHS case law in NZ. It helps establish a research agenda for research into that data as part of grey literature on OHS. The work may also help inform similar projects that are in hand or planned outside NZ, potentially enabling comparisons between Robens-style case law at an international level.

One of the drivers for this work was the need to identify cases involving a safe system of work. While complete data has yet to be gathered, our preliminary work makes starting such research easier. Such research will require thematic analysis of machine-readable decisions - summaries of cases in newspaper, magazine or website articles do not provide a clear link to safe system of work, system of work or similar terms (Peace et al., 2021). This is another area for further research.

The work reported here suggests that little enforcement activity has focused on the causes of occupational disease or harm to occupational health. The term "health" is defined in section 16 HSWA to mean "physical and mental health", suggesting an area for research into interventions that might have a long-term effect on the number of deaths due to occupational disease and improvement in occupational health.

The number of cases involving adventure activities or adventure tourism in the narrow sense of the Health and Safety at Work (Adventure Activities) Regulations (2016) or a wider sense was three, with two of these being prosecuted by Maritime NZ. After the Whakaari tragedy. WorkSafe NZ laid a total of 13 charges that have yet to be heard. Work reviewing the regulatory framework for such activities is in hand.

Perhaps most importantly, this work contributes to an understanding by students, practitioners and professionals of the "legal principles and comparative legal systems and regulatory frameworks" (INSHPO, 2017, p. 27). 
The dataset requires refinement of keyword terms and addition of the estimated 200 missing cases. Also, it is likely that Endnote will prove to be inadequate as a database for all the data about cases but, at this stage, it provides a starting point for qualitative research using the dataset.

When the dataset has been refined and expanded. it is planned to be exported in a format that can be imported into Endnote, Zotero or Mendeley, commonly used bibliographic software. This will help make the data more accessible to OHS professionals and academic researchers. It may also help lawyers to find data relevant to their work when advising PCBUs.

\section{References}

Adams, R. J., Smart, P., \& Huff, A. S. (2017). Shades of Grey: Guidelines for Working with the Grey Literature in Systematic Reviews for Management and Organizational Studies. International journal of management reviews : IJMR, 19(4), 432-454. https://doi.org/10.1111/ijmr.12102

Auger, P. (2017). Information Sources in Grey Literature. De Gruyter. https://doi.org/https://doi.org/10.1515/9783110977233

INSHPO. (2017). The Occupational Health and Safety Professional Capability Framework: A Global Framework for Practice International Network of Safety and Health Practitioner Organisations, Park Ridge, Il, USA. https://www.inshpo.org/

Lord Robens, A., Beeby, G., Pike, M., Robinson, S., Shaw, A., Windeyer, B., \& Wood, J. (1972). Safety and Health at Work: Report of the Committee, 1970-72 [Report Cmnd 5034]. HMSO, London. http://www.mineaccidents.com.au/uploads/robens-report-original.pdf

Mahood, Q., Van Eerd, D., \& Irvin, E. (2014). Searching for grey literature for systematic reviews: challenges and benefits. Research synthesis methods, 5(3), 221-234. https://doi.org/10.1002/jrsm.1106

Peace, C., Braun, C., Brophy, S., Jassim, M., Mills, E., Parul, Rose, A., \& Wichman, M. (2021). A structured approach to the concept of a safe system of work New Zealand Journal of Employment Relations, 46(2),

Peace, C., Lamm, F., Dearsly, G., \& Parkes, H. (2019). The evolution of the OHS profession in New Zealand. Safety Science, 120, 254-262.

Peace, C., Mabin, V., \& Cordery, C. (2017). Due diligence: a panacea for health and safety risk governance? Policy and Practice in Health and Safety, 15(1), 19-37. https://doi.org/10.1080/14773996.2016.1275497

Statistics New Zealand. (2006). Australian and New Zealand Standard Industrial Classification. Author. http://aria.stats.govt.nz/

Worksafe NZ (2019). Work-related health data [Infographic]. http://worksafe.govt.nz 